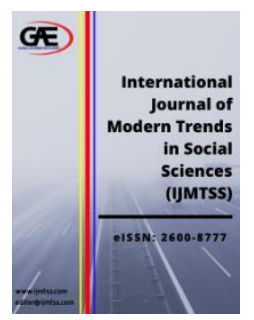

\author{
INTERNATIONAL JOURNAL OF \\ MODERN TRENDS IN \\ SOCIAL SCIENCES \\ (IJMTSS) \\ www.ijmtss.com
}

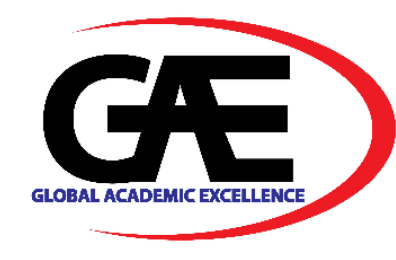

\title{
DIGITAL LITERACY OF SOCIAL MEDIA USERS IN MEDAN CITY IN FACING HOAX
}

\author{
Yovita Sabarina Sitepu ${ }^{1 *}$, Hendra Harahap ${ }^{2}$, Februati Trimurni ${ }^{3}$ \\ 1 Department of Communication Science, University of Sumatera Utara, Indonesia \\ Email: yovita.sabarina@usu.ac.id \\ 2 Department of Communication Science, University of Sumatera Utara, Indonesia \\ Email: hendrahrp@usu.ac.id \\ 3 Department of Public Administration, University of Sumatera Utara, Indonesia \\ Email: februati@usu.ac.id \\ * Corresponding Author
}

\section{Article Info:}

Article history:

Received date: 15.02 .2021

Revised date: 14.03 .2021

Accepted date: 22.03.2021

Published date: 31.03 .2021

\section{To cite this document:}

Sitepu, Y. S., Harahap, H., \& Trimurni, F.. (2021). Digital Literacy of Soial Media Users in Medan City in Facing Hoax. International Journal of Modern Trends in Social Sciences, 4 (15), 97-113.

DOI:10.35631/IJMTSS.415009

This work is licensed under $\underline{\text { C C BY 4.0 }}$

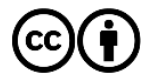

\begin{abstract}
:
Hoax and digitalization have become a threat to global democracy. During this pandemic, WhatsApp in collaboration with the Ministry of Communication and Informatics (Kominfo) has been successfully taken down 1, 759 hoaxes spreading on social media. Thus hoax content is circulating from January 23 to October 18,2020 . This study examines the literacy capability of social media users in Medan City in facing misinformation (Hoax). The purpose of this study is to describe the knowledge of social media users in Medan City regarding hoaxes; describing the process of spreading hoaxes among social media users in Medan City, as well as to identify the types of hoaxes mostly received and spread by social media users. The quantitative descriptive method is used in this study The samples of this study amount to 250 respondents selected in the accidental method. The results obtained from the aforementioned respondents show that respondents agreed that hoax is 'a deliberate fake news. They stated that they had not been forwarding 'splashy news' that they received and do fact-check. On the other hand, when asked about why the 'splashy news' was forwarded, the respondents reasoned that they received the news from someone they trusted. In addition, the respondents each stated that they thought the news was useful as they believed the news to be true. The types of hoaxes most frequently received include lucky draws, socio-politics, governance, and health.
\end{abstract}

Keywords:

Social Media, Hoax, Literacy 


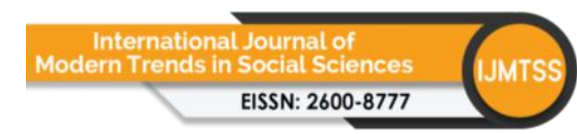

Volume 4 Issue 15 (March 2021) PP. 97-113 DOI 10.35631/IJMTSS.415009

\section{Introduction}

Information and Communication Technology that combines hardware such as computer and software for institutional, professional, or even personal use has already been part of human's daily life. We know this technology as digital media. Contents uploaded on digital media vary from sounds, images, videos, photos, texts, and so on and so forth. Media convergence is an inevitable thing and has been the feature of digital media (Herlina, 2019).

There are many different types of digital media also commonly referred to as "platform" to identify the variations in the digital media. These platforms, namely: content-based website, such as kompas.com; search engine, such as google and yahoo; user generated content, such as Wikipedia and forms of blogs; social media, such as Instagram, Facebook; and so on (Herlina, 2019, p.125-126).

Social media is the most used digital media platform especially YouTube, WhatsApp, Facebook, as well as Instagram. 2020 digital data for Indonesia by WeAreSocial shows that as of January 2020, there has been 160 million active users of social media and $99 \%$ of them utilized smartphones for access (Kemp, 2020).

As in print or broadcast media, using digital media requires its own skills or digital literacy. The concept of digital literacy combines the concept of media literacy, computer literacy, and information literacy (Bawden, as cited in Herlina, 2019). It is also advisable for active social media users to have a good digital literacy skill. If they do not possess the skills, for example, social media users are unable to utilize digital tools or facilities properly to identify and evaluate the information they receive.

During the last 2019 Election, a lot of back-and-forth information were received and disseminated by Indonesian citizens. Information was massively spread online as well as offline. The condition of information overload rendered recipients of the messages unable to analyze the truth or the accuracy of the messages.

This untrue, inaccurate, unverified information is known to the public as hoax. Hoaxes can be in the form of writing, photos, to videos. Hoaxes themselves are fabricated information, either by twisting the facts or obscuring information so that the true message cannot be received. Hoax covers misinformation, disinformation, and mal-formation (Nursahid et al., 2019).

Social media is stated as the digital platform in which hoax-spreading are most prevalent. Social media forms such as Facebook, Twitter, WhatsApp, Instagram, etc. are considered effective means of wide-spreading hoax. Survey results from DailySocial.id in 2018 towards 2032 smartphone users in Indonesia, found out that $53.25 \%$ said they frequently received hoaxes and $81.25 \%$ of respondents said they received hoaxes via WhatsApp as well as Instagram (Dailysocial.id, 2018).

In addition, the more time spent using social media is also considered a factor that influences the increasing hoax distribution. A research in 2018 conducted by Kunto Adi Wibowo, Detta Rahmawan and Eni Maryani regarding the spread of hoaxes in West Java, stated that the longer a person spend online, the more likely it is for them to spread hoaxes. Meanwhile, in terms of age, both the young and parents play a role as spreaders of fake news on social media (Wibowo, Rahmawan \& Maryani, 2019). 


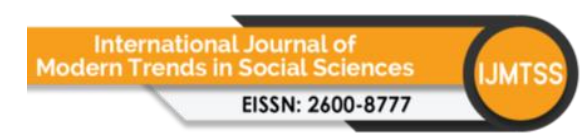

Volume 4 Issue 15 (March 2021) PP. 97-113

DOI 10.35631/IJMTSS.415009

During April 2019, The Ministry of Communication and Informatics (Kominfo) managed to identify as many as 486 hoaxes, and 209 amongst them came from the political category. Furthermore, from August 2018 to August 2019, the total number hoaxes identified was 1731. Hoaxes can be grouped into several categories, namely: politics, government, health, defamation, crime, natural disasters, SARA (refers to ethnicity, religion, race, and inter-group relations; short for Suku, Agama, Ras, dan Antar-golongan) (Maharani, 2019; Nursahid et al., 2019, p.3).

Research on measuring digital literacy, misinformation or hoaxes have been carried out a lot. Previous researches on digital literacy were conducted to students in junior high school and dental students. The result showed that only a few of junior high school stundents' perceived skills were related to their actual preformance. Moreover, research to dental students showed that social media is believed to help them in their professional course studies. And there were a difference between post-graduate and under graduate students in terms of knowledge of keywords, dental apps and reading research journals (Porat, Blau \& Barak, 2018; Saxena, Gupta, Mehrotra, Kamthan, Sabir, Katiyar \& Prasad, 2017).

A previous research on misinformation was conducted to investigate the role of epistemic belief in affecting Internet users' decision to share online health rumors. One of the result stated that epistemologically naive participants were more likely to share online health rumors than epistemologically robust ones (Chua \& Banerjee, 2017).

In Indonesia, many researches on misinformation were conducted. Two of them were done by Indonesian Telematics Society (Mastel) that conducted a national hoax survey in 2019 and DailySocial.id in 2018 conducted survey regarding the spreading of hoaxes via digital platforms in Indonesia. However, from all the researches, it is still difficult to find data about the spread of hoaxes among social media users in Medan City.

\section{Literature Review}

\section{Digital Literacy}

Martin, as quoted by Herlina (2019, p.127) defined digital literacy as the awareness, attitude, and ability of individuals in using digital tools and facilities in order to identify, access, manage, integrate, evaluate, analyze, as well as synthesize digital resources, build up new knowledge, create media expressions, and communicate with others.

There are four core competencies of digital literacy according to Tibor Koltay (in Herlina, 2019, p.128), i.e.:

1) Internet search, the ability to search for information combined with critical thinking to assess the information quality (truthfulness and credibility) from various sources.

2) Hypertext navigation, the ability to direct information with information connected in digital information.

3) Correct assembly of knowledge, the ability of someone to assemble pieces of information obtained from digital media.

4) Content evaluation, namely assessing the usefulness and relevance to real life so that the process of digital media facilitates constructive social action.

The issue of digital literacy has not been receiving more attention from the government. There has not been any education curriculum at the middle, upper, or higher level that includes digital 
literacy in it. This is unfortunate considering the increase in community's dependence to obtain information from digital media and thus a good level of digital literacy is required to be followed.

As published in Harian Kompas on January 20, 2020, the result of a survey by National Digital Literacy Movement (GNLD) Creative Cyber Movement (Siberkreasi) in March-November 2019 in 18 regencies/cities in Indonesia showed that $95.8 \%$ of 987 respondents stated that they had come across hoaxes. However, 54.4\% admitted that they sometimes confuse hoax contents with facts.

Livingstone and Thumim (in Herlina, 2019, p.128) mentioned three important things that audiences must master in this digital era, i.e.:

1) Technical skills in operating computers as well accessing internet as part of routine access to study, work, obtain news, and entertainment.

2) Understanding or practicing using digital media critically to avoid information overload, getting correct and reliable information, quality entertainment, useful knowledge to solve everyday problems.

3) Content production that facilitates creativity and collaboration for educational and entertainment purposes as well as a form of participation as a member of social groups and civil society so that they are involved in public decision-making.

The dimensions and perspectives of digital literacy as simply conveyed by Chetty et al. (2017) in the table below:

Table 1: Dimensions and Perspectives in Measuring Digital Literacy

\begin{tabular}{l|l|l|l}
\multicolumn{1}{c|}{ Dimensions } & \multicolumn{3}{c}{ Perspective } \\
\hline & \multicolumn{1}{c}{ Cognitive } & \multicolumn{1}{c}{ Technical } & Ethical \\
\hline Information (digital content) & Synthesis & Access, Use & Appropriate use \\
\hline $\begin{array}{l}\text { Computer (hardware and } \\
\text { software) }\end{array}$ & Evaluation & Use & Appropriate use \\
\hline $\begin{array}{l}\text { Media (text, sound, image, } \\
\text { video, social) }\end{array}$ & Critique, Creating & Navigation & Assess truth \\
\hline $\begin{array}{l}\text { Communication (non-linear } \\
\text { interactions) }\end{array}$ & Critique, Creating & $\begin{array}{l}\text { Content } \\
\text { development and } \\
\text { use }\end{array}$ & Appropriate use \\
\hline $\begin{array}{l}\text { Technology (tools for life } \\
\text { situations) }\end{array}$ & $\begin{array}{l}\text { Inventing, } \\
\text { Evaluating Tools }\end{array}$ & Use & Appropriate Use
\end{tabular}

Source: Chetty et al., 2017

\section{Hoax - Misinformation}

Based on the Great Dictionary of the Indonesian Language (KBBI), 'hoax' is defined as false news (KBBI Daring, 2016). On the other hand, according to Oxford Learner Dictionaries, 'hoax' is defined as an act intended to make somebody believe something that is not true, especially something unpleasant (Oxford learners dictionaries, 2021). In other words, hoax is an action taken to make other people believe in something that is not true which is usually something unpleasant. 


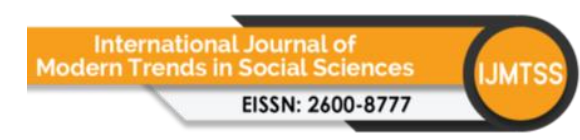

Volume 4 Issue 15 (March 2021) PP. 97-113

DOI 10.35631/IJMTSS.415009

Hoax is part of information chaos that includes misinformation, disinformation, and malinformation. Misinformation is information that is not true, however, the people who pass it on believe it to be. This false information is often disseminated without verifications from experts and the spreader does not cross check the information either. Aside from that, the spreader had no intention of harming other people. Examples of misinformation that often circulate e.g. about health, children kidnapping, etc.

Disinformation is false or untrue information which the spreader knows to be so but still deliberately chooses to spread it to deceive, threaten or harm other people. On the other hand, mal-information is false or incorrect information that is spread to threaten a person, party, or a group of people with certain identities. Mal-information is also known as hate speech (Nursahid et al., 2019, p.80). An example of mal-information is a message spread on social media that contains hatred-filled provocation against minority group, be it ethnic, religious, or certain sexual orientations.

There 7 types of misinformation and disinformation issued by First Draft News, namely: satire or parody, misleading content, imposter content, fabricated content, false connection, false context, and manipulated content. The following picture bellow shows the 7 types of misinformation and disinformation.

Satire or parody is an innuendo about someone or some certain events packaged with humor. Examples of satire or parody that are considered misinformation such as: the program Democrazy, presidential and vicepresidential candidates of Nurhadi-Aldo, and many more.

False connection is when elements in a certain news do not support each other such as when the title and content do not match. Example of this is when the headline is bombastic or often referred to also as clickbait and does not match with the content of the news (Nursahid et al., 2019, p.9-10).

Misleading content is the leading of recipient's perception regarding the content or an event (framing) for example contents that are the combination of several pieces of images, pieces of holy scriptures or research results that support the framing of a story. Forms like these can often be found in propagandas, political advertisements, and so on. False context is, for example, information about the concern among ethnic Chinese citizens over the spread of Corona with a photo in which a man of ethnic Chinese descent panic-buying basic necessities in a supermarket. Then came the clarification from the child of the person in the photo stating that his father was selling wholesale and every once in a while, would buy in large numbers at that supermarket (Nursahid et al., 2019, p.10).

Imposter content, for example, information that made on behalf of an official institution with the official logo but is actually fake. Manipulated content is in the form of modified images, videos, or writings so as to have different meaning from the original content. Fabricated content is information that is completely untrue and deliberately created by irresponsible parties. An example is Ratna Sarumpaet's lie (Nursahid et al., 2019, p.11-13).

\section{Methodology}

This research uses surveys and the quantitative descriptive methods. The surveys were conducted to obtain a comprehensive picture regarding the level of digital literacy for misinformation contents (hoaxes) which includes measurements based on dimensions and 
perspectives of digital literacy proposed by Chetty et al. (2017). Meanwhile, descriptive studies were used to provide an overview and explanation regarding social reality as well as the relationship between variables in relation to this reality.

The population in this research is the social media users in Medan City. As for the age group, the research population were those aged 15 to over 55 years. The sampling technique was done in purposive and accidental manner. The requirements for someone to be a sample in this research are residing or staying in Medan City for a long time; access or use social media; included in the age segments of this research.

250 respondents were declared the samples of this research with the age segmentation grouped based on cohort study, resulting in 5 age segments, namely: 13 to less than 17 years old; 17-20 years old; 21-36 years old; 37-55 years old; and over 55 years old.

\section{Measurement Method}

This research will measure several things, such as the following:

1) Demographic characteristics of social media users in Medan City, as measured by age, gender, monthly internet expense, internet usage activity, and so on.

2) Reasons for social media use, as measured through status acquisition and opinion expression, social interaction, information gathering, entertainment, and leisure/free time.

3) Pattern of social media use measured by duration and frequency of accessing social media.

4) Digital literacy level measured by using dimensions and perspectives of digital literacy.

\section{Data Collection}

Data collection was carried out by distributing questionnaires containing questions about digital literacy to social media users in Medan City in dealing with misinformation content. The occurring pandemic situation when this research was carried out forced more than $50 \%$ of the questionnaire to be made in the form of Google Form and distributed by personally contacting respondents via the WhatsApp application or by distributing to the WhatsApp groups of the field workers.

\section{Data Analysis Method}

Data analysis was carried out through descriptive statistical analysis applied to explore social media usage patterns, forms of misinformation content received by social media users and measures of digital literacy from social media users.

\section{Results and Discussion}

\section{Demographic Profile of Respondents}

\section{Age}

The number of respondents in this research was 250 people who were evenly distributed to each age group. Each age group consists of 50 respondents or $20 \%$ of the total respondents. 


\section{Gender}

Respondents in this research consists of 105 male respondents (42\%) and 145 female respondents $(58 \%)$. This is also in line with the population of Medan City where the female population outnumbers the male population.

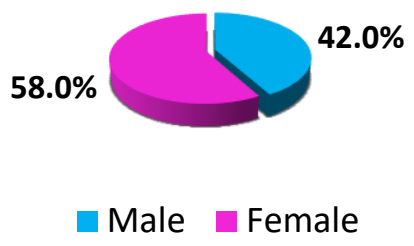

\section{Figure 1: Respondent Gender Distribution}

\section{Internet Usage Activity}

\section{Internet Cost}

The amount of internet cost spent by respondents each month can be seen in the pie chart below. There were 112 respondents or $44.8 \%$ who paid for the internet around Rp. 100,000.00 - Rp. $300,000.00$. Only $4.4 \%$ of respondents (11 people) who spent more than Rp. 500.000,00 per month.

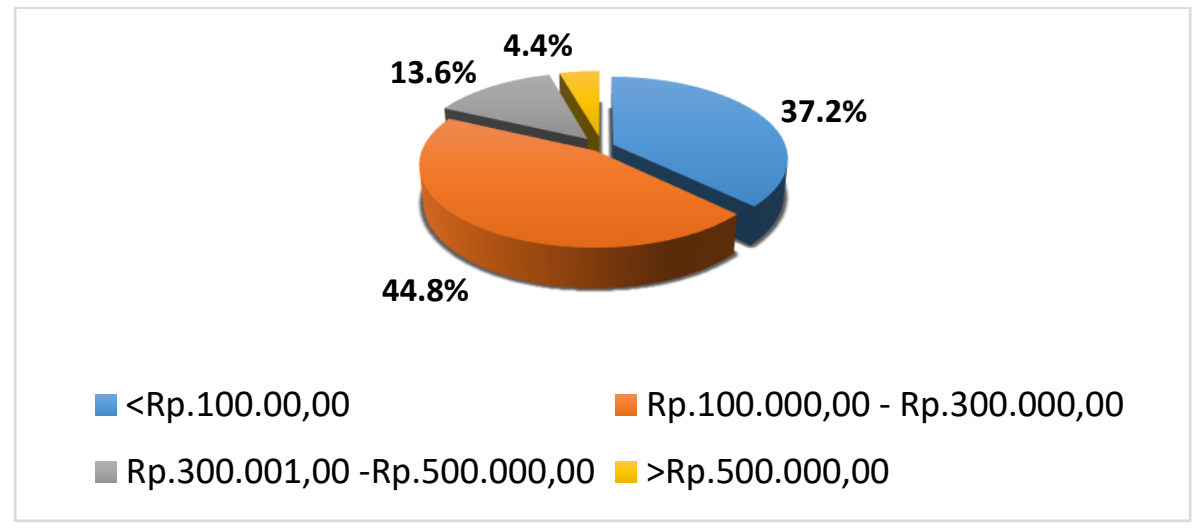

Figure 2: Internet Cost

\section{Internet Access}

There were 103 respondents (41.2\%) who accessed internet using internet credits/data packages. In addition, with not much of a difference, there were $101(40.4 \%)$ who accessed the internet using data packages and wifi, and only 46 respondents $(18.4 \%)$ accessed the internet using merely wifi.

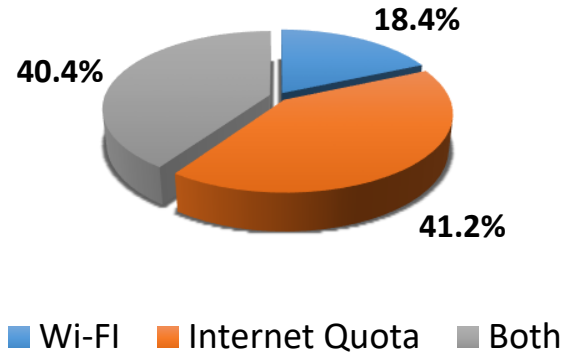




\section{Figure 3: Internet Access}

\section{Social Media Used by Respondent}

WhatsApp was the social media with the most users. A total of 239 respondents were using this messaging application. Instagram and YouTube followed next with user number of 197 and 183 respondents. Other social media used by respondents can be found on the bar chart below.

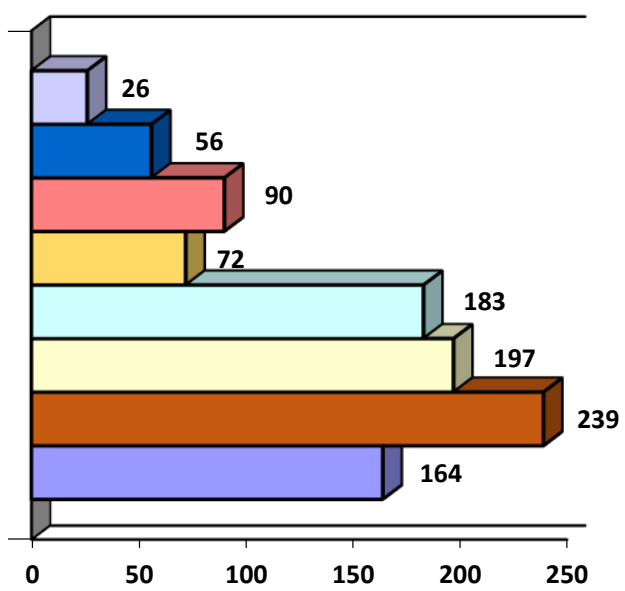

$$
\begin{aligned}
& \text { 口LinkedIn } \\
& \text { 口Telegram } \\
& \text { 口Line } \\
& \text { 口Twitter } \\
& \text { 口Youtube } \\
& \text { 口Instagram } \\
& \text { 口WhatsApp } \\
& \text { 口Facebook }
\end{aligned}
$$

Figure 4: Social Media Used

\section{Reasons for Using Social Media}

There are reasons to the use of social media. The most common reason is using media 'for social interaction'. There are 219 respondents who stated that reason. Moreover, 'seeking information' and as 'entertainment media' are other reasosn chosen by respondents for using social media. The desire 'to get recognition' is not the reason many respondents chose to use social media. There were only 20 respondents who stated that reason. Other reasons can be seen in the chart below.

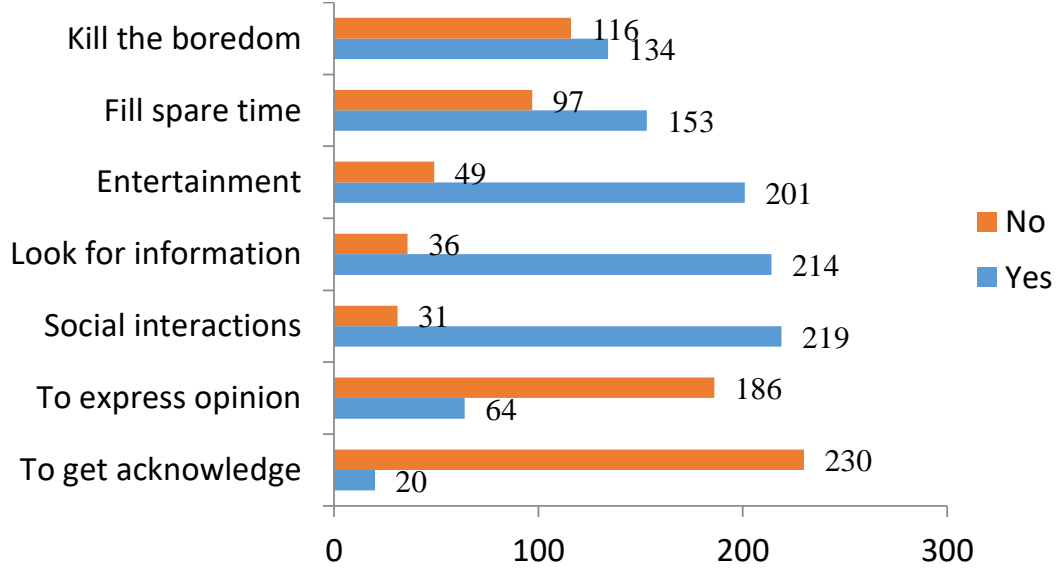

Figure 5: Reasons for Using Social Media

\section{Social Media Usage Patterns}

\section{Frequency of Social Media Use}

There are $41.2 \%$ of respondents who stated they accessed or used social media more than 10 times a day. Furthermore, there are 30\% of respondents who accessed social media 6-10 times Copyright $\odot$ GLOBAL ACADEMIC EXCELLENCE (M) SDN BHD - All rights reserved 
a day and $28.4 \%$ of respondents accessed 1-5 times a day. In the result of data collection, it was found that 1 person did not access social media in a day. The answer from this respondent is to be investigated further, if so, that person should not have been a respondent for this research.

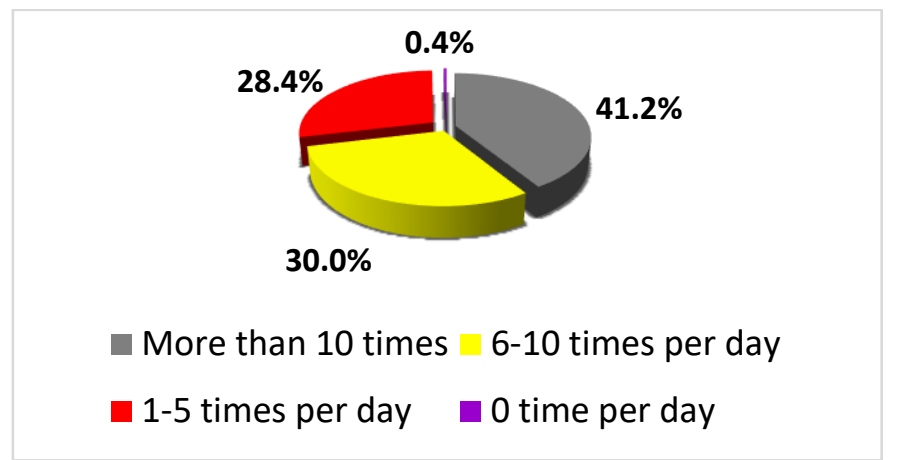

Figure 6: Frequency of Social Media Use

\section{Duration}

There were $32 \%$ of respondents who accessed social media for 1-3 hours a day followed by $31.2 \%$ who accessed 4-6 hours a day. Next, 29.6\% accessed for more than 6 hours a day and there were $7.2 \%$ of respondents who accessed social media less than 1 hour a day.

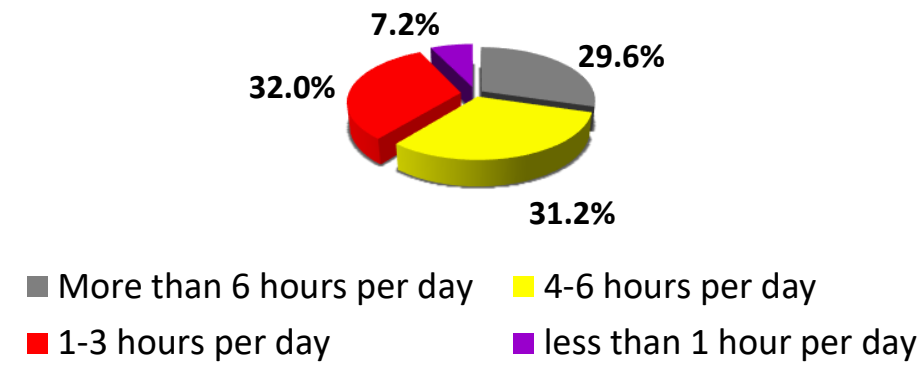

Figure 7: Duration of Social Media Access Per Day

Time of Access

Night time was the time most used by respondents to access social media. A total of 212 respondents or $84.8 \%$ accessed social media at night. Morning time was the time least used by respondents to access social media.

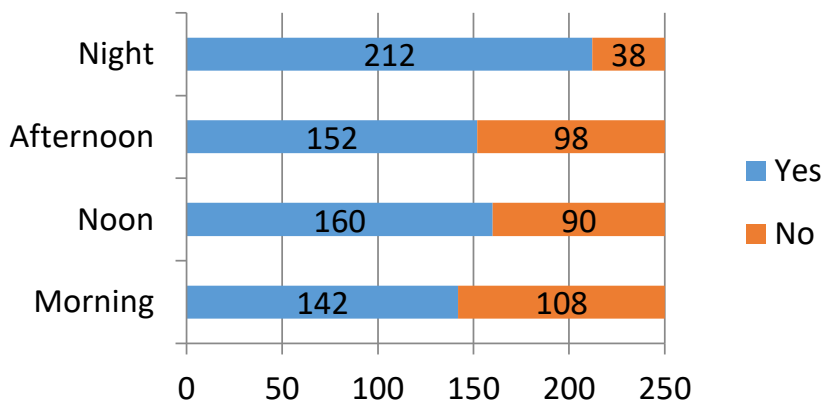

Figure 8: Time of Social Media Access 


\section{Understanding of Hoax}

\section{Definition of Hoax}

Upon answering the question to measure respondents' knowledge regarding misinformation (hoax), respondents were asked to determine whether the statements presented were the definition of hoax. The answers or responses of the respondents can be seen on the bar chart below.

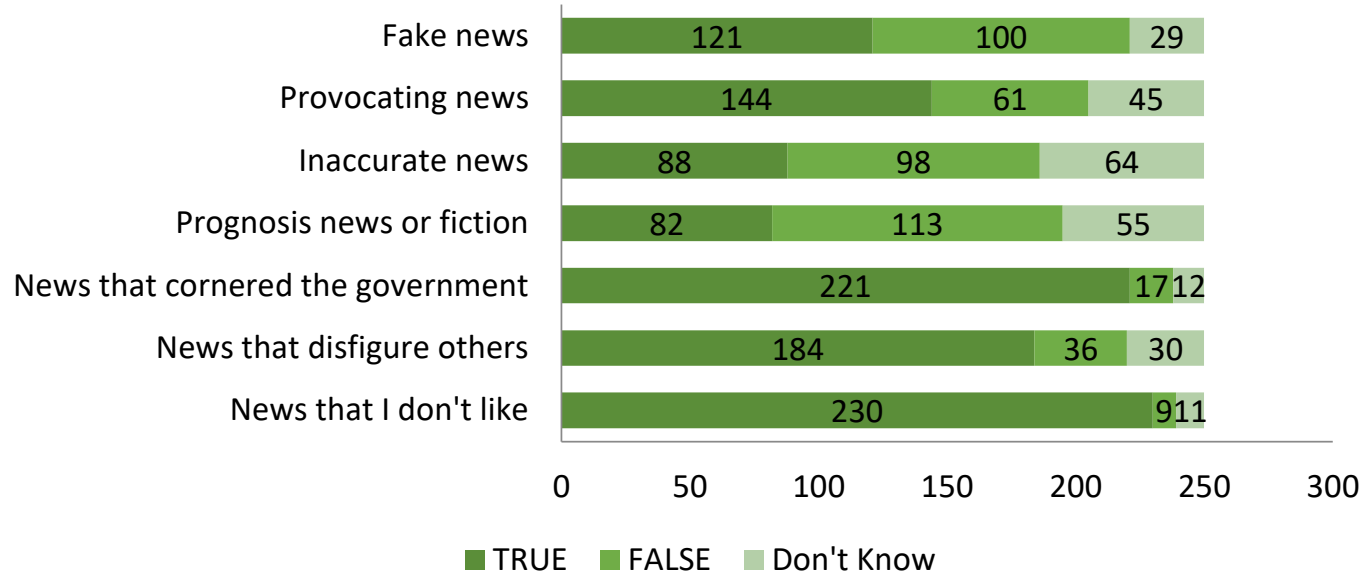

Figure 9: Definition of Hoax

\section{Trusted Media}

The figure below is the diagram consisting of respondent answers when asked about the media that they believed to be the source to obtain information. Online news portals were most picked media by respondents (177 respondents) as trusted media, followed by television media as well as social media. On the other hand, radio was the least picked media by respondents as the trusted media to obtain information. Only 45 respondents chose radio as their trusted media.

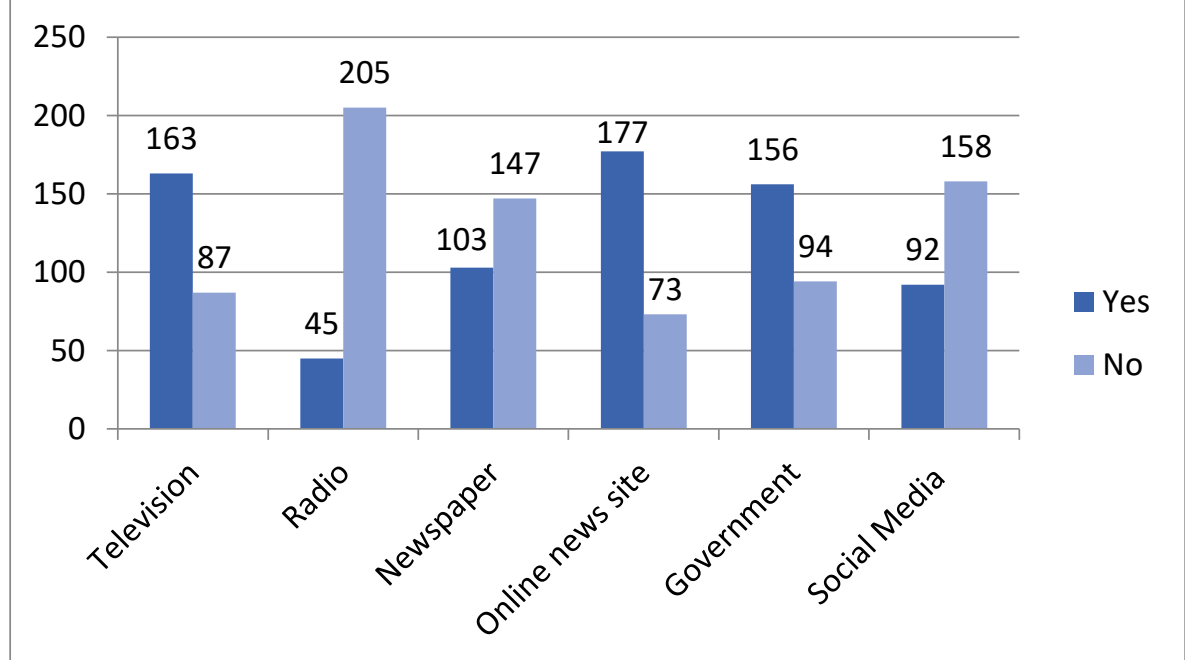

Figure 10: Trusted Media 


\section{Intensity of Receiving Hoax}

Respondents' intensity in receiving hoaxes could be considered frequent. A total of $35.2 \%$ of respondents admitted that they received hoaxes every day. On the other hand, $41.6 \%$ of respondents received hoax once a week and $23.2 \%$ of respondents received hoax once a month.

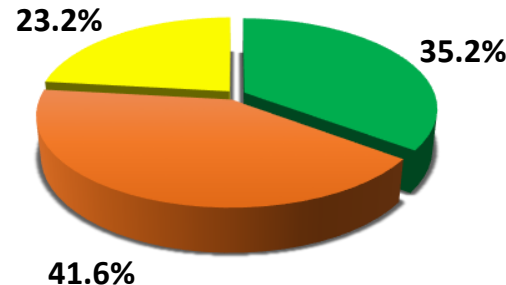

Everyday Once a week Once a month

Figure 11: Intensity of Receiving Hoax

\section{Actions When Receiving Splashy News}

There are several actions taken by respondents upon receiving splashy news on their social media. 225 respondents $(90 \%)$ did not proceed to forward the splashy news received and a total of 158 respondents $(63.2 \%)$ stated that they deleted the splashy news. $208 \%$ respondents $(83.2 \%)$ stated they checked the truth of the splashy news they received on social media.

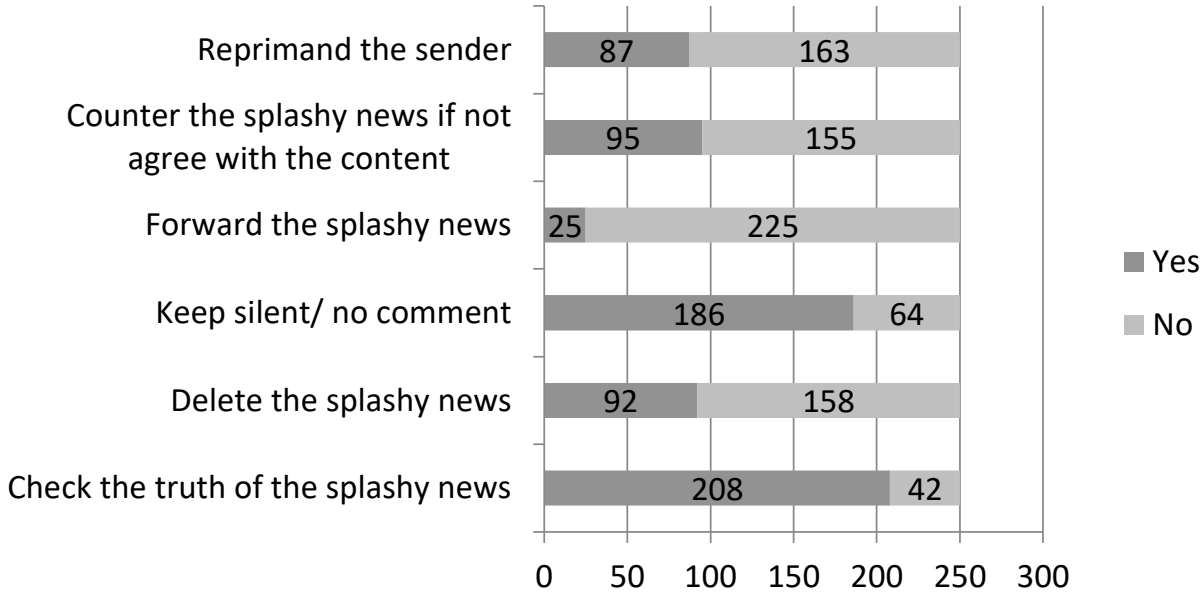

Figure 12: Actions When Receiving Splashy News

\section{Reasons for Forwarding Splashy News}

There are various reasons why someone would forward splashy news they received on social media. A total of 149 respondents $(59.6 \%)$ forwarded the splashy news because they received the news from people they trusted. The reason of 142 respondents $(56.8 \%)$ thought that the news they received could be useful and true. The reason "being the first to inform" and "for the splash/hype" were the two reasons least chosen by respondents. 


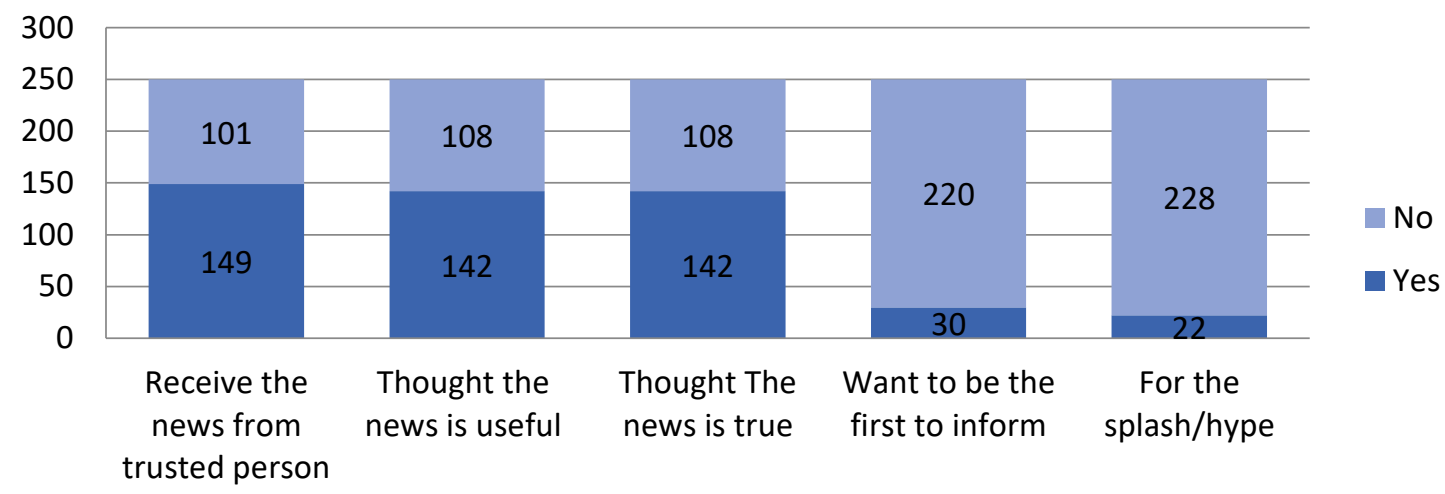

Figure 13: Reasons for Forwarding Splashy News

\section{Types of Hoaxes Received}

There are various types of hoaxes most commonly received by respondents. Data from the questionnaires shows that lottery is the type of hoax most picked by respondents as the type of hoax most frequently received by respondents. A total of 201 respondents chose this type of hoax that they received every day. Hoaxes related to socio-politics, government as well as health were also the type of hoax stated by many respondents as the type of hoax they most frequently received.

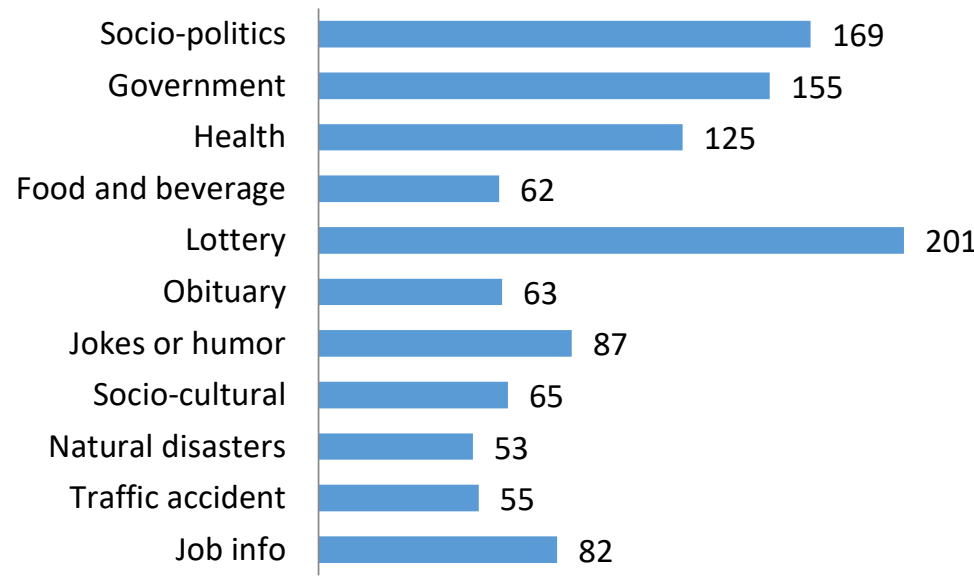

Figure 14: Hoax Types

\section{Digital Literacy Level}

\section{Hardware and Software- Capable of Using Search Engines}

The first aspect of digital literacy skills is measured by the ability to operate hardware and software. In this research, several questions were asked, among others, regarding the respondents' ability to use search engines, for example: Google. The answers of the respondents can be seen from the pie chart below. As many as $55.2 \%$ of respondents stated that they were very capable in using search engines. Only $3.6 \%$ of respondents stated their inability to use search engines. 


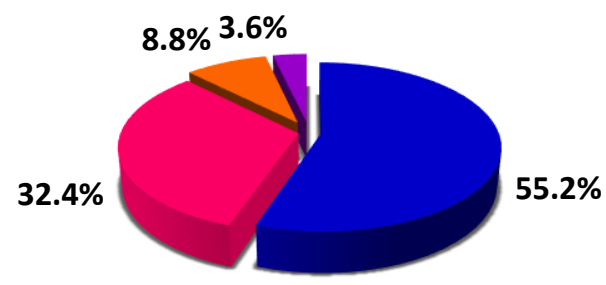

- Very capable Capable Less capable not capable

\section{Figure 15: Ability to Use Search Engines}

\section{Hardware and Software- Capable of Downloading}

A total of $50.7 \%$ respondents stated that they were very capable in downloading things like photos, videos, and documents. Only $3.2 \%$ of respondents stated that they were not capable.

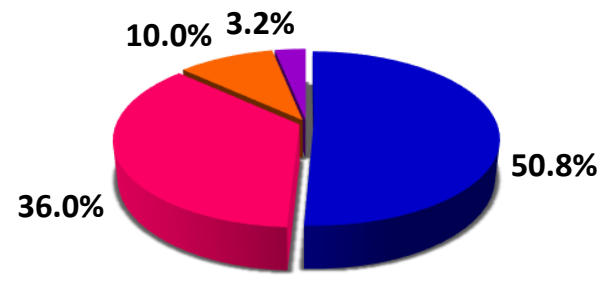

Very capable Capable Less capable Not capable

\section{Figure 16: Capable of Downloading}

\section{Capable of Uploading}

$47.2 \%$ of respondents stated that they were very capable in uploading things like photos, videos, as well as documents. Only $4.8 \%$ of respondents stated their inability in this.

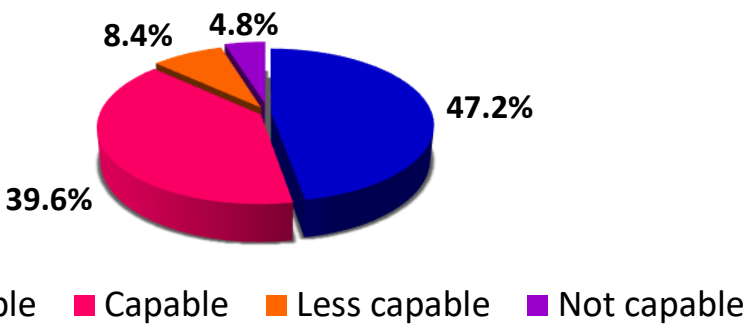

Figure 17: Capable of Uploading

\section{Media- Capable of Editing Photos}

The ability to edit/manipulate photos is one of the skills used to measure someone's digital literacy skills. Based on the answers from respondents, it was found that $45.6 \%$ of respondents stated that they were capable of editing photos, $21.6 \%$ stated that they were very capable. There were $10 \%$ of respondents who stated their inability in this skill. 


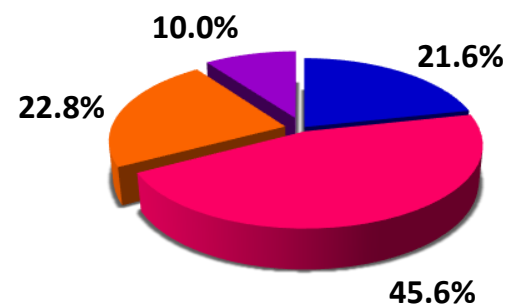

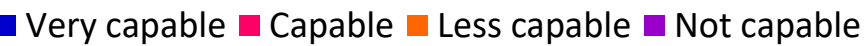

\section{Figure 18: Capable of Editing Photos}

\section{Communication- Fact-Checking Splashy News Using Internet}

The results of the questionnaires containing questions about respondents' ability to fact-check splashy news through internet, shows that $55.6 \%$ of respondents were capable of doing so. $22.8 \%$ respondents stated that they were very capable, $16.8 \%$ stated they there were less capable. Lastly, a total $4.8 \%$ stated that they were not capable of fact-checking splashy news using the internet.

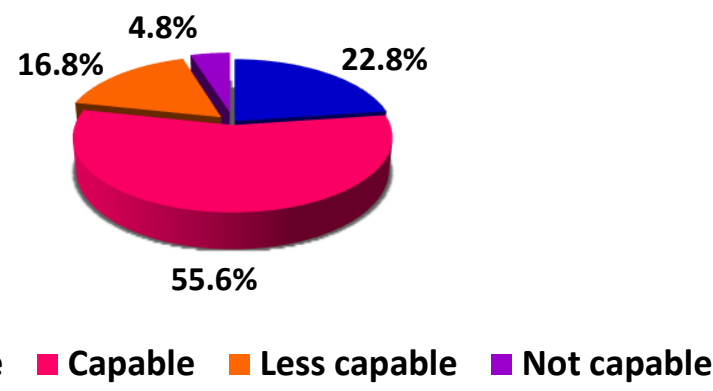

Figure 19: Fact-Checking Splashy News Using Internet

\section{Knowledge Test Regarding Hoax}

\section{News Link Unrelated to News Content}

At the end of the questionnaire, respondents were asked to observe a piece of information/news and determine whether that information/news were hoax or not. Respondents were asked to look at a news from an online news portal regarding information about the spread of Covid19. The results of this test, $61 \%$ of respondents answered the question wrong while $39 \%$ of respondents answered correctly.

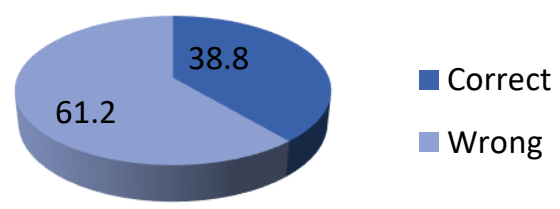

Figure 20: Knowledge Test: News Link, Not Related to the News Content 


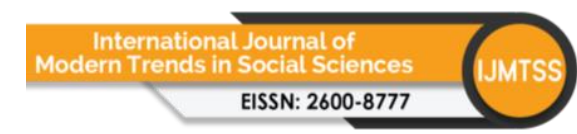

Volume 4 Issue 15 (March 2021) PP. 97-113 DOI 10.35631/IJMTSS.415009

\section{Discussion}

Based on the results shown above, it was found that, if viewed from the frequency and duration of accessing social media, it could be said that the respondents in this research had quite high frequency and duration. This is also in line with findings from Hootsuite for the year 2020, that Indonesians spend about 3 hours and 26 minutes on social media per day (wearesocial.com). The time used to access was more often at night.

The most had media social by respondents were WhatsApp followed by Instagram as well as Facebook. This is also in accordance with the report by Indonesian Digital Report 2020 released by Hootsuite stating that the top four most used/ active social media platforms are namely YouTube, WhatsApp, Facebook, as well as Instagram (Kemp, 2020).

This description is also in line with the three highest reasons for respondents' social media use, namely: to seek information, for social interaction, as well as to seek entertainment. As is well known, YouTube is the platform that is now widely used by users to seek entertainment as well as information. WhatsApp is the media social platform for exchanging messages while, as we all know, Instagram and Facebook are used for interacting with both familiar and new people.

There are several findings that also corroborate the findings of previous researches for example the media that respondents trust. Respondents chose online news portal as well as television as the media they trusted. Apart from that, information released by government was also something that could be trusted by respondents. Radio was the medium respondents trusted the least. This is in line with the findings of a decrease in the number of radio listeners over time. The results of Nielsen's survey in 11 cities, namely Bandung, Banjarmasin, Denpasar, Jakarta, Makassar, Medan, Palembang, Semarang, Surabaya, Surakarta, and Yogyakarta in 2016 stated that radio penetration was $37.6 \%$. However, since 2016 to 2018 radio penetration decreased to $34.3 \%$. Then, in 2019 survey result showed that there had been an increase to $36.3 \%$ (Zuhra, 2019, tirto.id).

The emergence of Spotify, Soundcloud, iTunes, as well as people's preference to directly watching video on the platform YouTube were also the cause of the decrease in people's desire to listen to radio. In addition, radio journalists were used to writing news in brief. This can also be attributed as the reason people were looking for more information on online news portals.

Aside from online news portals, social media was also trusted more by respondents in seeking information. This could explain why social media became the most common place for spreading hoaxes. Just like the results of a research conducted by Mastel in 2017, social media spread the most hoaxes.

The result of this survey noted that many respondents received hoaxes both every day or once a week. The types of hoaxes most commonly received, among others, lottery scam, sociopolitics, government, as well as health.

\section{Conclusion}

This research cannot be concluded broadly speaking as not all data have been analyzed. It is just that, to this moment, several things that become important notes of this research, namely:

1. Respondents' knowledge about the definition of hoax has been correct for the majority. However, for the part where hoaxes ere stated as 'news that I do not like', 'news that slanders 


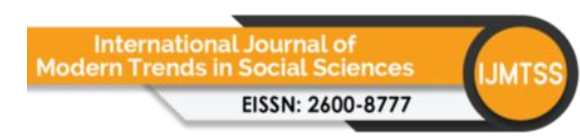

Volume 4 Issue 15 (March 2021) PP. 97-113

DOI 10.35631/IJMTSS.415009

other people', 'news that corners the government', 'inciting/persuading news', the response of respondents were still largely incorrect.

2. Regarding the process of spreading hoax news, when receiving splashy news, respondents forwarded the news because of several reasons namely: news from trusted people, thought the news to be useful, as well as thought the news to be true. With the high duration and frequency on social media, as well as the admission of the majority of respondents that they received hoaxes almost every day, thus this condition also supported the process of spreading hoaxes.

3. The types of hoaxes most frequently received by respondents in this research, three of the highest were namely: lottery scam hoax, socio-politics, government, as well as health. On the hand, hoaxes least chosen by respondents as the type of hoaxes received namely: natural disasters and traffic accidents.

\section{Acknowledgement}

This articel is an output from research that has been sponsored by Talenta Fund from Lembaga Penelitian University of Sumatera Utara, No: 4142/UN5.1.R/PPM/2020, April 27, 2020.

\section{References}

Chetty, K., Liu, Q., Wenwei, L., Josie, J., Gcora, N., \& Shenglin, B. (2017). Bridging the Digital Divide: Measuring Digital Literacy. Retrieved from https://www.G20insights.org accessed on 29 February 2020.

Chua, Alton Y.K., Banerjee, S. (2017). To Share or Not to Share: The Role of Epistemic Belief in Online Health Rumors. International Journal of Medical Informatics. http://dx.doi.org/10.1016/j.ijmedinf.2017.08.010

Dailysocial.id. (2018). Hoax Distribution Throgh Digital Platforms in Indonesia 2018. Retrieved from www.dailysocial.id and downloaded on 13 October 2019.

Herlina S, Dina. (2019). Literasi Media Teori dan Fasilitas. Bandung: PT Remaja Rosdakarya. https://medankota.bps.go.id accessed on 1 February 2020.

KBBI Daring. (2016). Retrieved from https://kbbi.kemdikbud.go.id/entri/

Kemp, Simon. (2020, February 18). Digital 2020: Indonesia. Retrieved from https://datareportal.com/reports/digital-2020-indonesia on 24 February 2020.

Kompas cetak. (2020, January 20). Tidak Bisa Musiman Mengatasi Hoaks Politik.

Nursahid, A., Kartika, A D., Rafsadie, I., Khairil, M., Astuti, S I., Mulyartono, S., \& Ali-Fauzi, I. (Eds). (2019). Buku Panduan Melawan Hasutan Kebencian. Jakarta: Pusat Studi Agama dan Demokrasi, Yayasan Paramadina dan Masyarakat Anti Fitnah Indonesia (Mafindo).

Maharani, T. (2019, May 1). Kominfo Identifikasi 486 Hoax Sepanjang April 2019, 209 Terkait Politik. Detik.com. Retrieved from https://news.detik.com/berita/d4532182/kominfo-identifikasi-486-hoax-sepanjang-april-2019-209-terkait-politik

Masyarakat Telematika Indonesia (Mastel). (2019). Hasil Survey Wabah Hoax Nasional 2019.

Retrieved from https://mastel.id/hasil-survey-wabah-hoax-nasional-2019/ on 29 February 2020.

Oxford learners dictionaries. (2021). Retrieved from https://www.oxfordlearnersdictionaries.com/definition/english/

Porat, E., Blau, I., \& Barak, A. (2018). Measuring Digital Literacies: Junior High-School Students' Perceived Competencies Versus Actual Performance. Computers \& Education. DOI: 10.1016/j.compedu.2018.06.030. 
Saxena, P., Gupta, S K., Mehrotra, D., Kamthan, S., Sabir, H., Katiyar, P., \& Prasad, S. V. S. (2017). Assessment of Digital Literacy and Use of Smart Phones among Central Indian Dental Students. Journal of Oral Biology and Craniofacial Research. https://doi.org/10.1016/j.jobcr.2017.10.001.

Wibowo, K A., Rahmawan, D., Maryani, E. (2019). In Indonesia, Young and Old Share Fake News on Social Media. The Conversation. Retrieved from https://theconversation.com/in-indonesia-young-and-old-share-fake-news-on-socialmedia-111433 on 17 February 2020.

Zuhra, Wan Ulfa Nur. (2019, Juli 1). Cara Radio Bertahan: Merambah ke Media Online hingga Jualan Obat. Tirto.id. Retrieved from https://tirto.id/cara-radio-bertahan-merambah-kemedia-online-hingga-jualan-obat-edmp 